\title{
Nasopharyngeal Cancer TNM Finding v6
}

National Cancer Institute

\section{Source}

National Cancer Institute. Nasopharyngeal Cancer TNM Finding v6. NCI Thesaurus. Code C64398.

A finding about one or more characteristics of nasopharyngeal cancer, following the rules of the TNM AJCC v6 classification system. 